\title{
Inequality and sustainable development: Insights from an analysis of the Human Development Index
}

\author{
David Castells-Quintana, ${ }^{1}$ Vicente Royuela, ${ }^{2}$ and Fabian Thiel $^{3}$
}

\begin{abstract}
:
In this paper, we connect two lines of research in the development economics literature: the analysis of the effect and transmission channels of inequality on economic development, and the discussion about the necessity for a broader measure for development. We estimate the association between income inequality and the Human Development Index (HDI) and its components in a panel of 117 countries over the period of 1970 to 2010 . In doing so, we find evidence for (1) a negative long-run association between inequality and human development, and (2) different short-run associations between inequality and different dimensions of human development: a positive one with economic development, but a negative one with educational outcomes, hinting at particular transmission channels. In addition, we detect (3) that those associations can be even more pronounced in countries with low levels of development, reconciling seemingly conflicting findings in the literature.
\end{abstract}

Keywords: inequality, sustainable development, Human Development Index, economic growth

JEL classification: $\mathrm{O} 10, \mathrm{O} 15, \mathrm{O} 40$

We are very grateful for helpful comments by Raul Ramos, Jose Maria Larru, and two anonymous reviewers. We also thank comments received at the UB PhD workshop, 2016 and at the XXth Encuentros de Economía Aplicada, 2017. We also acknowledge the support of ECO201675805-R and ECO2016-76855-P.

\footnotetext{
${ }^{1}$ Department of Applied Economics. Univ Autonoma de Barcelona. 08193 Bellaterra, Barcelona, Spain. David.Castells.Quintana@uab.cat. (Corresponding author).

${ }^{2}$ Universitat de Barcelona, AQR Research Group, Barcelona, Spain. vroyuela@ub.edu.

${ }^{3}$ Fabian_thiel@gmx.de
} 


\section{Introduction}

The debate about the impact of inequality on development has been for decades at the centre of a wide range of research. However, while it is nowadays widely acknowledged that development is much more than economic growth, the study of the effects of inequality on development has until now mainly focused on economic growth. The connection between inequality and other dimensions of sustainable development, like the social and environmental one, is still under-researched.

This paper aims to contribute to the study of the association between income inequality and the social dimension of sustainable development. In particular, we empirically analyse the impact of income inequality - proxied by the net Gini coefficient - and human development - as measured by the Human Development Index (HDI) and its components - in a panel of 117 countries over the period from 1970 to 2010. We compare our results on the relationship between inequality and HDI with those obtained with income-based measures (as standard in the literature to date). We also differentiate between short- and long-run associations and distinguish between each of the components of the HDI.

In relation to existing literature, previous studies have analysed the complexity of the relationship between inequality and development. In this line, several studies have identified both positive and negative channels for inequality to influence economic development, which are reviewed in the next section. Some of these channels are connected to other dimensions of development beyond income, like socio-political and educational factors, and affect income indirectly. This raises the need to consider the impact of inequality on different dimensions of development beyond income. Some works have analysed the impact of inequality on alternative dimensions of development, such as education or health, but to the best of our knowledge, no paper has studied these impacts using a more comprehensive framework such as the one behind the HDI.

As for inequality, other authors have recently focused one different "types" (see for instance, World Bank, 2005; Easterly, 2007; Marrero and Rodriguez, 2013; and CastellsQuintana and Royuela, 2017): structural inequality is thought to be connected to institutional factors and equality of opportunities, while market inequality is linked to market forces and equality of outcomes. Consequently, the two types of inequality work through different transmission channels and impact economic development differently (negatively or positively) and with different time dimensions (long- vs. short-run). According to Easterly (2007), in the long-run, structural inequality predicts lower levels of development, worse institutions, and a 
lower level of schooling, and therefore causes underdevelopment. Our paper aims to answer if and how inequality causes human underdevelopment, and therefore be socially unsustainable. For this, we use the HDI, which, in our view, offers a new perspective to the study of the inequality-development relationship.

The remainder of this paper is organized as follows: In the rest of this section we briefly review and merge the literature on inequality and economic development with the one on human development. Section 2 presents the data and specifies the empirical model to be estimated. The main results, along some robustness checks, are displayed and discussed in Section 3. Finally, Section 4 concludes.

\section{Economic and human development}

One fundamental motivation underlying the HDI can be traced back to Simon Kuznets. While being one of the fathers of the system of national accounts and GDP, Kuznets added in an early report to the US Congress that the welfare of a nation can scarcely be inferred from a measure of national income (Kuznets, 1934). Sen $(1985,1993,1999)$ introduced the relevance of other dimensions beyond income, putting the focus on human development and settling the basis for the subsequent design of the Human Development Index (HDI) as an alternative measure of well-being, prosperity and development (see also Mahbub ul Haq, 1994). The HDI is a multidimensional, composite index of human development, including health, knowledge and income, building on the idea that "people are the real wealth of a nation" (UNDP, 1990). The United Nations Development Programme (UNDP), in their Human Development Reports, has published the index annually since $1990 .^{4}$

The emergence of human development measures, as the HDI, can be seen as part of the extensive and still on-going discussion and criticism of GDP as the main indicator for economic progress and development (see for instance, Hicks and Streeten, 1979; Kenny, 2005; Stiglitz et al., 2008; European Commission, 2009; Felice, 2016). Despite its impact on policy and academic circles, the HDI has been subject to a considerable amount of criticism from its start. ${ }^{5} \mathrm{~A}$ critical point of criticism relates to the information captured by the HDI. While some

\footnotetext{
${ }^{4}$ See Online Supplementary Material for a detailed description of the used version of the HDI, the socalled Hybrid HDI.

${ }^{5}$ See Klugman et al. (2011) for a summary and review of criticism. See Morse (2003) and Bilbao-

Ubillos (2011) on the need to complement the HDI with an environmental dimensionof development.
} 
authors claim that the HDI is only redundant to GDP (McGillivray, 1991; Cahill, 2005; and Wolfers, 2009), others argue that despite similarities the two indicators react dissimilarly to the same causes and are in fact substantially different (Gray Molina and Purser, 2010; Klugman et al., 2011; Biagi et al., 2017). For instance, economic growth can promote human development via private incentives and consumption opportunities, and through higher tax revenue and public service expenditure, including education and health facilities (Ranis, 2004; Suri et al., 2011). In the other direction, advances in human development foster growth as healthier and more educated individuals can contribute more to the economic performance of a country (Ranis et al., 2000). Yet, economic growth does not necessarily translate into human development, and other dimensions of the HDI can remain unchanged even if GDP is thriving. ${ }^{6}$ In sum, income remains an important factor and is crucial for achieving higher standards of living and more opportunities, but it is today understood as one dimension among several that constitute human development. Consequently, an analysis of the HDI can bring more dimensions and insights to the study of development, and to the discussion on the impact of inequality.

\section{The effects of inequality on development}

The literature on the effects of inequality has mainly focused on effects on economic development, in particular on economic growth, but the evidence is not completely unanimous, unambiguous and conclusive. ${ }^{7}$ One important deduction to take away from this literature is the insight that the effect of inequality on economic growth is highly complex and heterogeneous; it might depend on several factors, including the extent, type, and persistency of inequality, the (initial) level of development, other country-specific characteristics, and the time horizon of analysis. Interestingly, most of the studies that find empirical evidence for a positive overall impact of inequality on subsequent economic growth, like Forbes (2000), rely on panel data, focusing on variation within countries over time, and relate to a short-run effect. On the other hand, studies based on cross-country variation and focusing on long-run effects tend to find a negative impact of inequality on economic performance (Alesina and Rodrik, 1994; Persson and Tabellini, 1994; Easterly, 2007; Herzer and Vollmer, 2012; Oechslin and Zweimüller,

\footnotetext{
${ }^{6}$ Dep (2015) finds that even the strong overall rank correlation can break down when analysing specific years or income groups, especially for middle and high-income nations.

${ }^{7}$ See Benabou (1996), De Dominicis et al. (2008), Ehrhart (2009), Galor (2009) and Neves and Silva (2013) for thorough and comprehensive surveys on the effects of inequality on economic growth.
} 
2014; Ostry et al., 2014; among others). Partridge (1997) and Barro (2000) find a growth effect that depends on the level of income, being negative in poor countries but positive in rich countries. Chen (2003), on the other hand, presents evidence suggesting that the effect depends on the initial income distribution itself, with the effect of inequality being positive when initial inequality is low and negative when it is high.

Considering the complexity and heterogeneity of the results, many studies have concentrated on investigating the different transmission channels through which inequality affects economic growth. The theoretical literature has identified a wide range of different positive and negative channels that contribute to an overall impact of inequality. The positive mechanisms circle around 1) higher savings rates (Kaldor, 1956), 2) imperfect capital markets with investment indivisibilities (Aghion et al., 1999) in physical and human capital, and 3) growthenhancing incentives created by inequality, for example for capital accumulation and innovations (Mirrlees, 1971). The negative mechanisms focus on 1) greater socio-political instability and risk of social conflict and unrest, implying uncertainty of property rights and reduction of investment (Alesina and Perotti, 1996), 2) higher redistributive pressure, which in turn may lead to economic distortions and disincentives (Alesina and Rodrik, 1994; Persson and Tabellini, 1994), as well as unproductive waste of resources by lobbying against redistribution (Acemoglu and Robinson, 2008; Stiglitz, 2009; Krugman, 2012), 3) credit-market imperfections and high set-up costs, which reduces the possibilities of low-income groups to invest in human capital (Galor and Zeira, 1993), 4) the importance of the middle class for aggregated demand and market size (Murphy et al., 1989; Todaro, 1997), and 5) the link between inequality, higher endogenous fertility rates, and reduced education and growth (Barro, 2000; Ehrhart, 2009).

For our analysis, it is both interesting and important to note that the positive transmission channels tend to be associated with an economic effect in the narrower sense; they have a more direct and immediate impact on economic outcomes like the GDP, precisely via savings and investment in physical capital. The negative mechanisms on the other hand, particularly 1), 2) and 5), are connected to broader effects: inequality affects opportunities as far as it damages education (human capital accumulation) as well as health outcomes. Of course, these dimensions have a further (long-term) impact on economic performance, although its initial (short-run) social development is far evident. 
The idea of differentiated impacts of inequality is also behind the idea of two distinct types (or components) of inequality. Inequality of opportunities (or structural inequality) refers to individual possibilities due to social, political and institutional structures, and is expected to manifest in poorer educational and health outcomes, and ultimately on lower levels of development. Inequality of outcomes (or market inequality) relates to unequal market outcomes for different levels of skill and education, creating necessary incentives for investment and innovation, and therefore potentially manifesting itself in higher short-run economic performance. Based on this distinction, Easterly (2007) focuses on the structural component of inequality, which he identifies using variables to proxy for factor endowments. He relies on cross-section analysis to show a long-run impact of inequality on economic development. Our study goes one step further by providing an analysis for human development and its different components (as captured by the HDI), and by using both cross-section and panel data to identify short- as well as long-run impacts of inequality.

Other papers have studied the effect of inequality on other aspects of human development, beyond purely economic development. Some works have focused on the impact on health outcomes (see Pickett and Wilkinson, 2015, and Chetty et al., 2016 for recent papers), while others have looked at educational attainment (including Easterly, 2007). Overall, there is a consensus that high income inequality leads to an increasing frequency of most of the problems associated with low social status within societies, including health problems, violence, high teenage birth rates, obesity and mental illness (Wilkinson and Pickett, 2009) and coalitions against education for the poor (Rajan and Zingales, 2006). However, none of these papers looks at several different effects taking place simultaneously. ${ }^{8}$

We are not aware of any paper studying the effects of inequality on human development, as measured by the HDI, and its components. The Human Development Report agenda has recently tried to account for inequality in human development when computing the Inequality-adjusted Human Development Index (IHDI). ${ }^{9}$ We do something complementary but

\footnotetext{
${ }^{8}$ Thorbecke and Charumilind (2002) provide a good review of the socioeconomic impact of inequality though several variables, inlucing economic growth, education and health. However, their study does not perform an econometric analysis.

${ }^{9}$ Many papers studied how to incorporate inequality into the HDI (see for instance Seth 2009). Others have also studied the evolution of inequality across countries in terms of the HDI (a recent paper is Martinez, 2016).
} 
different, which is to study the association between income inequality and human development (and its components), and to try to identify a causal effect using different specifications, estimation techniques, and identification strategies.

\section{Data and Empirical Model}

\section{Data}

Our main dependent variable is human development as measured by the HDI and its components. Since we are interested in historical trends we rely on the (Hybrid) HDI. This index considers past changes in the HDI calculation and has been introduced and published by the UNDP in the Human Development Report 2010 (UNDP, 2010). The index ensures comparability across countries and over time. It is available from 1970 to 2010, covering 135 countries that account for $92 \%$ of the world's population, and includes information on life expectancy, educational outcomes, and GDP.

For our key explanatory variable, inequality, we rely on Gini coefficients from the Standardized World Income Inequality Database - SWIID (Solt, 2014). ${ }^{10}$ The database combines information from the United Nations University's World Income Inequality Database (WIID) and from other secondary sources, with a custom missing-data imputation algorithm. SWIID maximizes comparability across countries and over time of income inequality data while maintaining the widest possible coverage across countries and years. The database provides comparable Gini coefficient of gross and net income inequality for 174 countries from 1960 to 2013, along with estimates of the uncertainty of these values. ${ }^{11}$ Consequently, we use estimation methods that are designed to deal with estimations on multiply imputed (MI) data (as suggested by Solt, 2014, 2015), and perform robustness checks with alternative inequality databases.

For control variables, we follow the literature of the determinants of cross-country differences in economic development, as well as the few empirical studies incorporating the

\footnotetext{
${ }^{10}$ The main econometric approach in estimating the inequality impact on development has been to introduce a single inequality measure into a growth equation. The most used and available measure is the Gini Coefficient. Other authors also employ the Theil index or shares or ratios of percentiles along the income distribution.

${ }^{11}$ In this paper, and following Solt $(2014,2015)$, we rely on the net Gini coefficients that reflect net (that is post-tax, post-transfer) income inequality.
} 
HDI. For the most part they rely on the same or similar controls. ${ }^{12}$ These controls include Investment (as percentage of GDP), Government Consumption (also as percentage of GDP), Openness (as the share of exports plus imports relative to GDP), Inflation, and Urbanization (as percentage of population living in urban areas). ${ }^{13}$ The data for these variables is taken either from the Penn World Tables (Heston et al., 2012) or the World Bank's World Development Indicators (World Bank, 2016). Finally, following Easterly (2007), we consider geographical variables for identification in our cross-section estimates: wheat to sugar ratio, in logs (lwheatsugar), describing whether land is more suitable to grow wheat or sugar cane, and a ratio of the country's land that is located in the tropics (tropicar). Appendix A1 comprises all our variables, their definition, the source from which the data is collected, and information about the available country and year coverage.

We work with data in five-year intervals, as standard in the literature, between 1970 and 2010. With such information, we plot in Figure 1 the first part of the descriptive analysis, while at the same time motivating the use of the HDI by addressing the issue of redundancy the question whether the HDI and GDP measure the "same thing". The first panel shows a strong correlation between the HDI and the income index, frequently pointed out by critics of the HDI. Panel B plots the income index against the "Social HDI", the geometric mean of the education and health indices. It displays that the relationship begins to weaken while still being strong. We see substantial variation and the correlation weakens even more in panel C, when plotting the absolute difference between 2010 and 1970 of the income index and the HDI respectively. When doing the same for the change in the income index and the Social HDI in the panel D, the positive relationship totally breaks down and even turns negative.

\section{[INSERT FIGURE 1]}

The descriptive statistics for main variables are summarized in Table 1, with the HDI rescaled to 100 . We can see that while most of the variation of both the HDI and the Gini Index are observed between countries, there is also some variation within countries over time. Figure 2 graphs the correlation between HDI and the Gini Coefficient and displays the overall, within, and between variations. The overall correlation between the HDI and the Gini is

\footnotetext{
${ }^{12}$ See Barro (1991) and Sala-i-Martin et al. (2004) for seminal papers cross-section papers on the determinants of economic growth.

${ }^{13}$ Theory and empirical evidence suggest a positive effect of agglomeration on urban areas on growth and development (see for instance Castells-Quintana and Royuela, 2014).
} 
negative. Interestingly, there is a slightly positive correlation in the within variation, but the correlation between countries is negative and larger in terms of absolute value. While this mere correlation does not allow for any causal inference, this fact could be in line with the reviewed empirical literature where we observed that time-series and fixed effects models tend to suggest a positive (short-run) effect of inequality on development, whereas cross-country studies seem to find a negative (long-term) impact.

\section{[INSERT TABLE 1]}

\section{[INSERT FIGURE 2]}

Table 2 presents correlation values between our key variables in more detail. There is a strong negative correlation of 0.47 in the raw data (overall variation) that depends on average country performance. This reflects the fact that many countries with low levels of inequality also tend to have high HDI, such as Norway and New Zealand. On the contrary, many other countries have over the whole considered period a high Gini index and a low HDI, such as Lesotho and Kenya. The overall correlation does not change with respect to the raw data when controlling for time effects (-0.47). However, it does change drastically and even is slightly positive when controlling for country, but not time effects $(0.11)$. When we control for both country and time fixed effects, the correlation turns negative again, but gets close to zero (-0.09). This reflects different evolutions for different countries. For instance, if we compute the correlation of the annual evolution of the Gini index and the HDI we find a correlation of -0.33 in New Zealand and +0.52 in Norway, while such time series correlation for Lesotho is +0.33 and -0.33 for Kenya. ${ }^{14}$

\section{[INSERT TABLE 2]}

\section{Empirical Model}

The descriptive analysis performed revealed a negative overall bivariate correlation between inequality - as measured by the Gini coefficient - and human development - as measured by

\footnotetext{
${ }^{14}$ Appendix A2 shows the correlation for all our variables, both for the raw data (overall variation) and for the data after controlling for country and time effects.
} 
the HDI. Does this negative relationship hold when we consider our control variables and other determinants of development established in the literature? Is there a causal effect of inequality on long-run human development? To try to answer these questions, we follow the literature on the determinants of long-run economic growth and development to investigate if inequality can help us predict levels of development. Thus, our specification becomes:

$$
\begin{aligned}
& H_{i, t}=\alpha+\beta_{1} \text { Inequality }_{i, t}+\beta_{2} \text { GovConsumption }_{i, t}+\beta_{3} \text { Investment }_{i, t}+ \\
& \beta_{1} \text { Openness }_{i, t}+\beta_{1} \text { Inflation }_{i, t}+\beta_{1} \text { UrbanPop }_{i, t}+u_{i, t}
\end{aligned}
$$

Where $H D I_{i, t}$ is the Hybrid-HDI in country $i$ and time $t$, Inequality is our key variable, GovConsumption, Investment, Openness, Inflation, and UrbanPop are our main controls, and $u_{i, t}$ is a country-time specific shock. We define our time dimension, $t$, in five-year intervals from 1970 to 2010 , to control for the business cycle and given the persistency of inequality (and as commonly done in the related literature). The decision on the time length of the interval is motivated by three reasons: i) given the strong cross-sectional component of the variance of inequality measures, the use of low frequency data would amplify the error component without adding more information; but, ii) enlarging the time length would substantially decrease the sample size of the panel; and iii) most empirical works in the inequality-development literature using panel data also rely on 5-year intervals. In any case, we check that our results are not significantly affected by the time length. To avoid endogeneity, in our estimations, all explanatory variables are lagged five years. Inequality, as our main explanatory variable of interest, is lagged by five, or alternatively, ten years. We tested for different lag structures for robustness of the results. Below we also check for the inclusion of other controls and further address endogeneity concerns.

\section{Results and Discussion}

\section{Inequality and human development: panel estimates}

We estimate our main underlying model specified in equation (1) using different panel data estimation techniques, while always considering the multiple imputation nature - and thus uncertainty - of our inequality data. We cluster standard errors by country. We estimate the 
model for the HDI as well as for its components. Time and country fixed effects (FE) are included to control for global shocks and for unobserved country-specific characteristics. Main results are presented in Table 3. Column 1 considers the HDI as the dependent variable, whilst columns 2, 3 and 4, consider the different components of the index: the log of GDP, life expectancy (health), and literacy rate (education). FE estimates yield a non-significant association between the inequality and the HDI (column 1). Looking at the different components, we find a positive and significant association between the evolution of inequality and that of GDP per capita (column 2). By contrast, the association between the evolution of inequality and the literacy rate, as a proxy for educational outcomes, is negative and statistically significant only at the $10 \%$ level (column 4). ${ }^{15}$ For simplicity, tables in main text do not report coefficients for all considered controls. In the appendix, we do report coefficients for our control variables. Controls tend to exhibit expected signs, with investment and agglomeration showing a positive and significant relationship with human development. ${ }^{16}$

\section{[INSERT TABLE 3]}

As a composite measure of human development, results in Table 3 suggest that inequality is associated differently with different components of the HDI. The positive association with income per capita is in line with previous studies also relying on panel fixed-effects estimates (i.e., Li and Zou, 1998, Forbes, 2000). ${ }^{17}$ The negative association with educational outcomes is in line with the idea of inequality creating barriers for human capital accumulation (i.e., Galor and Moav, 2004, and Easterly, 2007).

The non-significance of our FE estimates in column 1 of Table 3 does not necessarily imply that there is no significant relationship between inequality and human development. The coexistence of two opposing associations between inequality and different components of

\footnotetext{
${ }^{15} \mathrm{We}$ have checked the robustness of our results to different time intervals, from 3 to 10 -year intervals. Higher frequency increases the amount of observations but also the noise in the data. Longer intervals reduce the noise but lower the number of observations. In any case, qualitatively, our main results hold for different time intervals.

${ }^{16}$ In all tables, we report significance at $1 \%, 5 \%$ and $10 \%$, although we interpret the latter figure as a marginal sign of association. Note that multiple imputation estimations do not allow to calculate the overall adjustment of the model. However, we have also estimated all our models using the mean of the Gini from the Solt data for ever country, every year, to check that our model has a good overall fit (78\% of the variation in HDI, without including country-fixed effects, and up to $86 \%$ in the between estimator).

${ }^{17}$ Barro (2000), Chen (2003) and Voitchovsky (2005) also find a similar positive effect of inequality on economic growth, but depending on further countries' characteristics.
} 
human development may explain the non-significance of the coefficient for inequality in column 1. Furthermore, FE estimates consider only variation within countries over time, so results can be interpreted as related to the short run (see for instance Partridge, 2005). By contrast, OLS and Between Estimates (BE) can be considered as capturing a long-run association (see for instance Baltagi and Griffin, 1984; and Pirotte, 1999). Appendix A3 shows FE but also OLS and BE results. Differently to FE estimates, OLS and BE yield a negative and significant association between inequality and the HDI. These opposing results between the short $(+)$ and the long run (-) are also in line with the literature on the effects of inequality on economic development.

\section{Non-linearities based on the level of development}

According to the literature, the overall association between inequality and development may be different for different groups of countries, particularly with respect to their level of development. To investigate whether the inequality-human development relationship also differs for different levels of development, we incorporate into our model a dummy variable for developed countries, and interact this dummy with inequality. ${ }^{18}$ Column 1 of Table 4 displays FE estimates with the HDI as the dependent variable. The estimated coefficient for inequality in developing countries (the base category) is now positive and statistically significant (at the $10 \%$ level). This result is in line with Galor and Moav (2004), who suggest that in early stages of development, when physical capital accumulation is the prime engine of growth, inequality is growth-enhancing via higher propensity to save and the role of credit market imperfections, but irrelevant for growth in developed countries. In fact, for developed countries the two estimates sum to a small negative coefficient that is not significantly different from zero. Estimates in column 2, where income per capita is now the dependent variable, also yield a positive and significant impact of inequality for developing countries, reinforcing the idea behind Galor and Moav (2004). By contrast, estimates in column 4 yield a negative and significant

\footnotetext{
${ }^{18}$ In accordance with the Human Development Reports we define as developed countries those classified as possessing a "very high human development", that means an HDI of above 0.8 . The final list basically coincides with that of the UN. Notice that the level dummy is omitted in fixed effects estimations as our definition of development is based on 2010 values and hence does not change over time.
} 
association of inequality with educational outcomes for developing countries, but not for developed countries. ${ }^{19}$ This latter result is in line with Barro (2000), who suggests that inequality is negatively correlated with growth in low-income countries, but positively in high-income countries. According to Barro, inequality has a negative effect on development in developing countries through higher fertility rates and lower investments in education. ${ }^{20}$

\section{[INSERT TABLE 4]}

In sum, when we look at the association of inequality with different components of the HDI, and differentiate by levels of development, seemingly opposing results in the literature can be reconciled. Controlling for differences in the level of development allows us to capture a negative association of inequality with development, related to education (human capital accumulation) and hinting at the endogenous fertility approach; and a positive association of inequality with development related to physical capital accumulation, and hinting at the higher aggregate savings approach. ${ }^{21}$

\section{A cross-section instrumental variables approach}

So far, we have relied on panel estimates to benefit from all the information in our database, and we have identified interesting associations between inequality and different components of human development. We have controlled for several time-variant variables potentially influencing the inequality-development relationship, and FE estimates have allowed us to control for omitted time-invariant factors. To take a step further, we now turn to a cross-section framework. Several reasons justify this. One of these reasons is the fact that inequality is a variable highly persistent over time, which limits the potential for analysis of causal effects using panel techniques (see for instance Easterly, 2007). Furthermore, when using FE estimates, if the underlying causal determinants of the development process are persistent, the

\footnotetext{
${ }^{19}$ Although the interaction parameter is positive, it is not statistically significant. In fact, if we estimate the same regression for the subsample of developed countries the coefficient is close to 0 and insignificant.

${ }^{20}$ In Barro (2000) the overall effect of inequality (for the world sample) turns insignificant when controlling for fertility, but the development-dependent results hold.

${ }^{21} \mathrm{We}$ also considered inequality in linear and quadratic form. Results yield a positive coefficient for inequality and a negative coefficient for its square, in line with Chen (2003). However, our coefficients, reported in Appendix A4, are not always statistically significant and therefore have to be taken with caution.
} 
long-run cross-sectional impacts will be subsumed into the fixed effects (see for instance Fallah and Partridge, 2007). In the study of the impacts of inequality, key time-invariant factors, like the quality of institutions are precisely those to which a negative effect of inequality has been related, which means that FE estimates may be upward - positively - biased, at least if we are interested in the long run. Finally, but of course related, finding valid instrument for inequality is an extremely difficult task, especially if we look for time-variant instruments. Papers using external instruments have relied on a cross-section framework. ${ }^{22}$ Consequently, a cross-section framework allows us to use exogenous variation to address endogeneity concerns and get closer to identifying a causal effect of inequality on human development. ${ }^{23}$

We estimate a cross-section version of equation (1), regressing the HDI measured in 2010 on inequality measured as the average between 1980 and 2005. Results are presented in Table 5. Column 1 presents OLS estimates. Inequality is negative and significantly associated with the HDI. This result is in line with panel OLS and BE estimates. Columns 2 to 5 present estimates by Instrumental Variables (IV). Following Easterly (2007), we rely on exogenous variation given by geographical variables. We use information on land endowments given by two variables: i) a wheat to sugar ratio, in logs (lwheatsugar), describing whether land is more suitable to grow wheat or sugar cane, and ii) a ratio of the country's land that is located in the tropics (tropicar). Different land endowments led to different crop specialization and class structures, which in turn explain (structural) inequality. In IV estimates, we lose 19 observations compared to OLS estimates due to data availability for the chosen instruments. In all our IV estimates results yield a negative and highly significant coefficient for inequality. These results are in line with, and complement, results in Easterly (2007), and support the idea of a causal long-run effect of inequality on human development. ${ }^{24}$

\section{[INSERT TABLE 5]}

\footnotetext{
${ }^{22}$ A cross-sectional analysis has also allowed disentangling two opposing effects of inequality - one positive and one negative - of long-run economic growth, and the transmission channels to which these two effects relate (see Castells-Quintana and Royuela, 2017).

${ }^{23}$ To perform these cross section estimates we do not rely on data by Solt, but use Gini coefficient from the World Bank, which are more reliable (they are not the outcome of a multiple imputation logarithm). In this regard, these estimations can also be considered as a robustness check to measurement error in inequality in our panel estimates.

${ }^{24}$ The econometric validity of our instruments is reinforced by standard tests reported in Tables 5 and 6. However, as most instruments (almost by definition) are far from perfect, and ours are not the exception. Land endowments may influence human development through other mechanisms different than inequality (and thus violating the exclusion restriction). Below we adress this issue by controlling for other potential mechanisms like institutional development.
} 
In line with Easterly (2007), we perform several robustness checks to our IV estimates. In column 1 of Table 6 , we check that the negative coefficient for inequality on the HDI is robust to excluding the Americas and therefore not driven by a North America-South America divide. In column 2, we check that the result holds when including continental dummies, and in column 3, we check that it holds when including dummies to capture colonial origin. Finally, in columns 4 and 5, we control for two potential confounding factors - variables potentially correlated with inequality and with development: ethnic fractionalization (Ethfrac), and the quality of government $(Q o G)$. Several authors have suggested that the development-reducing effect of geographical endowments - that may be associated with higher inequality - mainly works through institutions (Engerman and Sokollof, 2002; and Acemoglu and Robinson, 2008). Our proxy for institutions yields a non-significant coefficient. However, its inclusion significantly reduces the size and significance of the coefficient for inequality. This result suggests that indeed part of the negative long-run effect of inequality on human development may work through institutional development: inequality leads to worse institutions, which in turn hinder human development. But even controlling for institutions, inequality still has a direct negative effect on human development.

\section{[INSERT TABLE 6]}

The estimated effect of inequality on human development is not negligible. Our IV estimates (i.e., coefficients from column 2 of Table 5) suggest that a country A with a Gini coefficient 9 points (one standard deviation) lower than that of country B is expected to have a HDI around 8.9 points higher than that of country B. For the median country in our sample (with respect to HDI in 1990), Colombia, this result implies that a decrease (increase) of the Gini coefficient in one standard deviation translates into an increase (decrease) in HDI ranking of more than 20 positions, out of the 135 considered countries in the Hybrid-HDI original dataset. 


\section{Conclusions}

Building on previous works on the links between income inequality and economic development, this paper has tackled a relatively neglected relationship in the literature, that between income inequality and human development. To do so, we have performed several econometric techniques, relying on a cross-country panel combing data on inequality - as measured by Gini coefficients, and data on sustainable human development - as measured by the HDI, from 1970 to 2010. Using the HDI has allowed us to consider alternative dimensions of development beyond income, to better study and understand the different effects of inequality on human development, with important policy implications.

Our results suggest that, in the short-run, the impact of inequality can be substantially different for the different dimensions of the HDI. While there may be a positive short-run impact of inequality on economic growth, there is a negative effect on educational outcomes. Both effects seem to be particularly strong in developing countries. But our results also provide strong evidence of a negative long-run effect of inequality on sustainable human development. This negative effect seems to be robust to several controls, estimation techniques, and identification strategies, and is in line with and complements the literature that suggests a long-run negative effect of inequality on economic development. In other words, inequality not only causes economic underdevelopment, it also seems to cause human underdevelopment.

Our work has both limitations and directions for further research. First, we have used the HDI as a proxy for human development. Even though this a comprehensive and a wide known measure, other indices could be considered, such as those incorporating the distribution of income, or those looking at individual happiness or satisfaction with life. Second, we have not explicitly examined the role of each of the transmission channels for inequality to impact human development (this has been done with inequality and economic growth in Castells-Quintana and Royuela, 2017). Third, while we have worked with different time intervals, more could be done to understand the timing for inequality to affect human development. All in all, understanding the relationship between inequality and human development, as critical for a form of development that is socially sustainable, clearly deserves further research. 


\section{References}

Acemoglu, D., \& Robinson, J. A. 2008. Persistence of Power, Elites, and Institutions. The American Economic Review, 98(1): 267-293.

Aghion, P., Caroli, E. \& Garcia-Penalosa, C. 1999. Inequality and Economic Growth: The Perspective of the New Growth Theories. Journal of Economic Literature, 37(4): 1615-1660.

Alesina, A. \& Perotti, R. 1996. Income Distribution, Political Instability, and Investment. European Economic Review, 40(6): 1203-1228.

Alesina, A. \& Rodrik, D. 1994. Distributive Politics and Economic Growth. The Quarterly Journal of Economics, 109(2): 465-490.

Baltagi, B. \& Griffin, J. M. 1984. Short and Long Run Effects in Pooled Models. International Economic Review, 25(3): 631-45.

Barro, R. J. 1991. Economic Growth in a Cross Section of Countries, The Quarterly Journal of Economics, 106(2): 407-443.

Barro, R. J. 2000. Inequality and Growth in a Panel of Countries. Journal of Economic Growth, 5(1): 5-32.

Benabou, R. 1996. Inequality and Growth. In NBER Macroeconomics Annual 1996, Volume 11 (pp. 11-92). MIT Press.

Biagi, B., Ladu, M. G. \& Royuela, V. 2017. Human Development and Tourism Specialization. Evidence from a Panel of Developed and Developing Countries. International Journal of Tourism Research, 19(2), pp. 160178.

Bilbao-Ubillos, J. 2011. The limits of Human Development Index: The complmentarity role of economic and social cohesion, development strategies and sustainability, Sustainable Development, 21(6): 400-412.

Cahill, M. B. 2005. Is the Human Development Index Redundant? Eastern Economic Journal, 31(1): 1-5.

Castells-Quintana, D. \& Royuela, V. 2014. Agglomeration, inequality and economic growth. The Annals of Regional Science, 52(2): 343-366.

Castells-Quintana, D. \& Royuela, V. 2017. Tracking positive and negative effects of inequality on long-run growth. Empirical Economics, 53(4): 1349-1378.

Chen, B. L. 2003. An inverted-U relationship between inequality and long-run growth. Economics Letters, 78(2): 205-212.

Chetty, R., Stepner, M., Abraham, S., Lin, S., Scuderi, B., Turner, N., Bergeron, A. \& Cutler, D. 2016. The Association Between Income and Life Expectancy in the United States, 2001-2014. Journal of the American Medical Association, 315(16): 1750-1766.

De Dominicis L., Florax, R. \& de Groot, H. 2008. A meta-analysis on the relationship between income inequality and economic growth. Scottish Journal of Political Economy, 55(5): 654-682.

Dep, S. 2015. Gap between GDP and HDI: Are the Rich Country Experiences Different from the Poor? IARIWOECD Special Conference: “W(h)ither the SNA?", Paris, France, April 2015.

Easterly, W. 2007. Inequality Does Cause Underdevelopment: Insights from a New Instrument. Journal of Development Economics, 84(2): 755-776.

Ehrhart, C. 2009. The Effects of Inequality on Growth: A Survey of the Theoretical and Empirical Literature, ECINEQ WP, 107.

Engerman, S. \& Sokoloff, K. 2002. Factor Endowments, Inequality, and Paths of Development Among New World Economies. NBER Working Paper No. 9529.

European Commission. 2009. GDP and Beyond: Measuring Progress in a Changing World. Communication from the Commission to the Council and the European Parliament, COM (2009) 433 (final): Brussels.

Fallah, B. N. \& Partridge, M. 2007. The elusive inequality-economic growth relationship: are there differences between cities and the countryside? The Annals of Regional Science, 41(2): 375-400.

Felice, E. 2016. The misty grail: The search for a comprehensive measure of development and the reasons for GDP primacy. Development and Change, 47(5): 967-994.

Forbes, K. J. 2000. A Reassessment of the Relationship between Inequality and Growth. American Economic Review, 94(4): 869-887.

Galor, O. 2009. Inequality and Economic Development: The Modern Perspective. Edward Elgar Publishing.

Galor, O. \& Moav, O. 2004. From Physical to Human Capital Accumulation: Inequality and the Process of Development. The Review of Economic Studies, 71(4): 1001-1026.

Galor, O. \& Zeira, J. 1993. Income Distribution and Macroeconomics. Review of Economic Studies, 60(1): 3552.

Gray Molina, G. \& Purser, M. 2010. Human Development Trends Since 1970: A Social Convergence Story, UNDP-HDRO Occasional Papers, (2010/2).

Haq, M ul. 1994. Reflections on Human Development (No. HDOCPA-1994-11). Human Development Report Office (HDRO), United Nations Development Programme (UNDP).

Harrod, R. F. 1939. An Essay in Dynamic Theory. The Economic Journal, 49(193): 14-33. 
Herzer, D, \& Vollmer, S. 2012. Inequality and growth: evidence from panel cointegration. Journal of Economic Inequaliy, 10(4): 489-503.

Heston, A., Summers, R., \& Aten, B. 2012. Penn World Table Version 7.1. Center of comparisons of production, income and prices at the University of Pennsylvania.

Hicks, N. \& Streeten, P. 1979. Indicators of Development: The Search for a Basic Needs Yardstick. World Development, 7(6): 567-580.

Kaldor, N. 1956. Alternative Theories of Distribution. The Review of Economic Studies, 23(2): 83-100.

Kaldor, N. 1957. A Model of Economic Growth. The Economic Journal, 67(268): 591-624.

Kenny, C. 2005. Why Are We Worried About Income? Nearly Everything that Matters is Converging. World Development, 1(33): 1-19.

Klugman, J., Rodriguez, F. \& Hyung, J. C. 2011. The HDI 2010: New Controversies, Old Critiques. Journal of Economic Inequality, 9(2): 249-288.

Krugman, P. 2012. End This Depression Now! WW Norton \& Company.

Kuznets, S. 1934. National Income, 1929-1932. 73rd US Congress, 2nd Session, Senate Document no. $124,7$.

Li, H. \& Zou, H. F. 1998. Income Inequality is not Harmful for Growth: Theory and Evidence. Review of Development Economics, 2(3): 318-334.

Marrero G, \& Rodriguez, J. 2013. Inequality of opportunity and growth. Journal of Development Economics, 104: $107-122$

Martinez, R. 2016. Inequality decomposition and human development. Journal of Human Development and Capabilities, 17(3): 415-425.

McGillivray, M. 1991. The Human Development Index: Yet Another Redundant Composite Development Indicator? World Development, 19(10): 1461-1468.

Mirrlees, J. A. 1971. An Exploration in the Theory of Optimum Income Taxation. The Review of Economic Studies, 38(2): 175-208.

Morse, S. 2003. Greening the United Nations’ Human Development Index? Sustainable Development, 11(4): 183-198.

Murphy, K., Shleifer, A. \& Vishny, R. 1989. Income Distribution, Market Size, and Industrialization. The Quarterly Journal of Economics, 104(3): 537-64.

Neves, P. C. \& Silva, S. M. 2013. Survey article: inequality and growth. Journal of Development Studies, 50: 121.

Oechslin, M. \& Zweimüller, J. 2014. Inequality and growth: the neglected time dimensión. Journal of Economic Growth, 19(1): 81-104.

Ostry, J., Berg, A. \& Tsangarides, C. 2014. Redistribution, inequality and growth. IMF Staff Discussion Note (SDN/14/02).

Partridge, M. 1997. Is inequality harmful for growth? A note. American Economic Review, 87(5): 1019-1032

Partridge, M. 2005. Does Income Distribution Affect US State Economic Growth? Journal of Regional Science, 45(2): 363-394.

Pickett, K. \& Wilkinson, R. 2015. Income inequality and health: A causal review. Social Science \& Medicine, 128: 316-326.

Pirotte, A. 1999. Convergence of the static estimation toward the long run effects of dynamic panel data models, Economics Letters, 63(2): 151-158.

Persson, T. \& Tabellini, G. 1994. Is Inequality Harmful for Growth? The American Economic Review, 84(3): 600-621.

Rajan, R., \& Zingales, G. 2006. The Persistence of Underdevelopment: Institutions, Human Capital, or Constituencies? NBER Working Paper No. 12093.

Ranis, G. 2004. Human Development and Economic Growth. Yale University Economic Growth Center Discussion Paper (887).

Ranis, G., Stewart, F. \& Ramirez, A. 2000. Economic Growth and Human Development. World development, 28(2): 197-219.

Sala-i-Martin, X., Doppelhofer, G. \& Miller, R. 2004. Determinants of long-term growth: A Bayesian averaging of classical estimates (BACE) approach. American Economic Review, 94: 813-835.

Sen, A. 1985. Commodities and Capabilities. Amsterdam: North-Holland.

Sen, A. 1993. Capability and Well-Being. In: M. Nussbaum and A. Sen (eds). The Quality of Life. Oxford: Clarendon Press: 30-43.

Sen, A. 1999. Development as Freedom. Oxford: Oxford University Press.

Seth, S. 2009. Inequality, interactions, and human development. Journal of Human Development and Capabilities, 10(3): 375-396.

Solt, F. 2014. The Standardized World Income Inequality Database, Working paper. SWIID Version 5.0, October 2014. 
Solt, F. 2015. On the Assessment and Use of Cross-National Income Inequality Datasets. The Journal of Economic Inequality, 13(4): 683-691.

Stiglitz, J. 2009. The Global Crisis, Social Protection and Jobs. International Labour Review, 148(1- 2): 1-13.

Stiglitz, J., Sen, A. \& Fitoussi, J. 2008. Issues Paper, Commission on the Measurement of Economic Performance and Social Progress, CMEPSP Issues Paper No. 25/07/08-1.

Suri, T., Boozer, M., Ranis, G. \& Stewart, F. 2011. Paths to Success: The Relationship Between Human Development and Economic Growth. World Development, 4(39): 506-522.

Thorbecke, E. and Charumilind, Ch. 2002. Economic inequality and its socioeconomic impact. World Development 30(9): 1477-1495.

Todaro, M. 1997. Economic Development. London: Longman.

UNDP. 1990. Human Development Report 1990. New York: UNDP.

UNDP. 2010. Human Development Report 2010 - The Real Wealth of Nations: Pathways to Human Development. New York: UNDP.

Voitchovsky, S. 2005. Does the profile of income inequality matter for economic growth? Journal of Economic Growth, 10(3): 273-296.

Wilkinson, R. \& Pickett, K. 2009. Income Inequality and Social Dysfunction. Annual Review of Sociology, 35 : 493-511.

Wolfers, J. 2009. What Does the Human Development Index Measure? New York Times Blog: Freakonomics. Posted May 22, 2009. http://freakonomics.blogs.nytimes.com/2009/05/22/what-does-the-human-development-indexmeasure/.

World Bank. 2005. World Development Report 2006: Equity and Development. Washington, DC: World Bank. World Bank. 2016. World Development Indicators 2016. World Bank Publications. 


\title{
Appendices for "Inequality and human underdevelopment: insights from an analysis of the HDI"
}

\author{
Appendix A1. Variables Description
}

\begin{tabular}{|c|c|c|c|}
\hline Label & Description & Source & Coverage \\
\hline Hybrid HDI & $\begin{array}{l}\text { Hybrid HDI values, } \\
\mathrm{HDI}=(\operatorname{Lifex} * \mathrm{EDUx} * \mathrm{GDPx})^{\wedge}(1 / 3)\end{array}$ & \multirow{11}{*}{$\begin{array}{l}\text { United Nations Development Programme - } \\
\text { Human Development Report } 2010\end{array}$} & \multirow{11}{*}{$\begin{array}{l}1970-2010 \text { for } 135 \\
\text { countries, balanced } \\
1970-2010 \text { for } 135 \\
\text { countries, balanced } \\
1970-2010 \text { for } 135 \\
\text { countries, balanced } \\
1970-2010 \text { for } 135 \\
\text { countries, balanced } \\
1970-2010 \text { for } 135 \\
\text { countries, balanced } \\
1970-2010 \text { for } 135 \\
\text { countries, balanced } \\
1970-2010 \text { for } 135 \\
\text { countries, balanced } \\
1970-2010 \text { for } 135 \\
\text { countries, balanced } \\
1970-2010 \text { for } 135 \\
\text { countries, balanced } \\
1970-2010 \text { for } 135 \\
\text { countries, balanced } \\
1970-2010 \text { for } 135 \\
\text { countries, balanced }\end{array}$} \\
\hline HDI Rank & Hybrid HDI ranks & & \\
\hline Life & Life Expectancy & & \\
\hline Lifex & $\begin{array}{l}\text { Health Index, Lifex }=(\text { Life-20 }) / 83.17(\mathrm{Ja}- \\
\text { pan,2010)-20) }\end{array}$ & & \\
\hline Lit & Adult Literacy Rate & & \\
\hline Litx & $\begin{array}{l}\text { Literacy Index, Litx=(Lit-0)/(99(several coun- } \\
\text { tries, several years)-0) }\end{array}$ & & \\
\hline GER & Combined Gross Enrolment Rate & & \\
\hline GERx & $\begin{array}{l}\text { Combined Gross Enrolment Rate Index, } \\
\text { GERx }=(\text { GER-0)/(115.82(Australia,2002)-0) }\end{array}$ & & \\
\hline$E D U x$ & Education Index, $\mathrm{EDUx}=\left(\operatorname{Lit}{ }^{*} \mathrm{GERx}\right)^{\wedge}(1 / 2)$ & & \\
\hline GDP & GDP per capita, PPP\$ & & \\
\hline$G D P x$ & 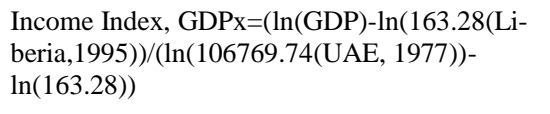 & & \\
\hline Gini & $\begin{array}{l}\text { Net (post-tax, post-transfer) Income Inequality } \\
\text { Gini Indices (100 imputations) }\end{array}$ & $\begin{array}{l}\text { Standardized World Income Inequality Da- } \\
\text { tabase (SWIID), Version 5.0, October } \\
\text { 2014, Solt (2014). }\end{array}$ & $\begin{array}{l}1960-2013 \text { for } 174 \\
\text { countries, unbal. }\end{array}$ \\
\hline GovConsumption & $\begin{array}{l}\text { Government Consumption Share of PPP Con- } \\
\text { verted GDP Per Capita at } 2005 \text { constant prices } \\
\text { [rgdpl] (\%) }\end{array}$ & \multirow{3}{*}{$\begin{array}{l}\text { Penn World Table 7.1, Nov 2012, Heston } \\
\text { et al. (2012). }\end{array}$} & $\begin{array}{l}1950-2011 \text { for } 189 \\
\text { countries, unbal. }\end{array}$ \\
\hline Investment & $\begin{array}{l}\text { Investment Share of PPP Converted GDP Per } \\
\text { Capita at } 2005 \text { constant prices [rgdpl] (\%) }\end{array}$ & & \multirow{2}{*}{$\begin{array}{l}1950-2011 \text { for } 189 \\
\text { countries, unbal. } \\
1950-2011 \text { for } 189 \\
\text { countries, unbal. }\end{array}$} \\
\hline Openness & Openness at 2005 at constant price (\%) & & \\
\hline Inflation & Inflation, GDP deflator (annual \%) & $\begin{array}{l}\text { World Development Indicators, April } \\
\text { 2016, World Bank (2016). }\end{array}$ & $\begin{array}{l}1960-2015 \text { for } 214 \\
\text { countries, unbal. }\end{array}$ \\
\hline UrbanPop & Urban population (\% of total) & & \\
\hline $\begin{array}{l}\text { lwheatsugar } \\
\text { tropicar }\end{array}$ & $\begin{array}{l}\text { Proportion of land suitable to wheat compared } \\
\text { to land suitable to sugar (in logs) } \\
\text { Ratio of the country's land that is located in the } \\
\text { tropics }\end{array}$ & Easterly (2007) & \\
\hline Ethfrac & Ethnic fractionalisation & Sala i Marti et al. (2004) & \\
\hline$Q o G$ & Quality of Government Index & $\begin{array}{l}\text { PRS Group (2012), International Country } \\
\text { Risk Guide }\end{array}$ & \\
\hline
\end{tabular}


Appendix A2. Correlation coefficients

Table A2.1. Correlation - Raw Data (Overall Variation)

\begin{tabular}{lccccccc}
\hline & HDI & Gini & GovCons & Investment & Openness & Inflation & UrbanPop \\
\hline HDI & 1 & & & & & & \\
Gini & $-0.47^{* * *}$ & 1 & & & & & \\
GovCons & $-0.38^{* * * *}$ & $0.13^{* * * *}$ & 1 & & & & \\
Investment & $0.25^{* * *}$ & -0.06 & $-0.10^{* *}$ & 1 & & & \\
Openness & $0.20^{* * *}$ & -0.04 & 0.01 & $0.19^{* * * *}$ & 1 & & \\
Inflation & -0.03 & $0.11^{* *}$ & -0.01 & -0.07 & -0.06 & 1 & \\
UrbanPop & $0.83^{* * *}$ & $-0.37^{* * *}$ & $-0.37^{* * *}$ & $0.17^{* * *}$ & $0.14^{* * *}$ & 0.01 & 1 \\
\hline
\end{tabular}

Note: *** $\mathrm{p}<0.01, * * \mathrm{p}<0.05,{ }^{*} \mathrm{p}<0.1$

Table A2.2. Correlation - Country and Time Effects Controlled Data

\begin{tabular}{lccccccc}
\hline & HDI & Gini & GovCons & Investment & Openness & Inflation & UrbanPop \\
\hline HDI & 1 & & & & & & \\
Gini & $-0.09^{* *}$ & 1 & & & & & \\
GovCons & 0.03 & -0.05 & 1 & & & & \\
Investment & $0.21^{* * *}$ & -0.01 & $-0.08^{*}$ & 1 & & & \\
Openness & 0.05 & $0.08^{*}$ & 0.02 & $0.14^{* * *}$ & 1 & & \\
Inflation & -0.04 & $0.10^{* *}$ & 0.01 & -0.01 & -0.01 & 1 & \\
UrbanPop & $0.36^{* * *}$ & -0.04 & $0.09^{* *}$ & 0.01 & -0.04 & -0.04 & 1 \\
\hline Note**** $<0.01, * *$ & & & & & & \\
\hline
\end{tabular}


Appendix A3. Table A3. Inequality and HDI, and its components. Several estimation techniques

\begin{tabular}{|c|c|c|c|c|}
\hline Dependent variable: $H D I t$ & $\begin{array}{c}(1) \\
\text { OLS }\end{array}$ & $\begin{array}{c}(2) \\
\text { OLS }\end{array}$ & $\begin{array}{l}\text { (3) } \\
\mathrm{BE}\end{array}$ & $\begin{array}{l}\text { (4) } \\
\text { FE }\end{array}$ \\
\hline Gini $_{t-2}$ & $\begin{array}{c}-0.3591 * * * \\
(0.0387)\end{array}$ & $\begin{array}{c}-0.3831 * * * \\
(0.0382)\end{array}$ & $\begin{array}{c}-0.4731^{* * *} \\
(0.0920)\end{array}$ & $\begin{array}{c}0.0715 \\
(0.0514)\end{array}$ \\
\hline GovConsumption $_{t-1}$ & $\begin{array}{c}-0.3204 * * * \\
(0.1233)\end{array}$ & $\begin{array}{c}-0.3194 * * * \\
(0.1232)\end{array}$ & $\begin{array}{c}-0.5081^{* * *} \\
(0.1700)\end{array}$ & $\begin{array}{l}-0.0098 \\
(0.1237)\end{array}$ \\
\hline Investment $_{t-1}$ & $\begin{array}{c}0.2105 * * * \\
(0.0578)\end{array}$ & $\begin{array}{c}0.2538 * * * \\
(0.0566)\end{array}$ & $\begin{array}{c}0.4615 * * * \\
(0.1084)\end{array}$ & $\begin{array}{c}0.0665^{* *} \\
(0.0264)\end{array}$ \\
\hline Openness $s_{t-1}$ & $\begin{array}{l}0.0162 * \\
(0.0085)\end{array}$ & $\begin{array}{c}0.0047 \\
(0.0090)\end{array}$ & $\begin{array}{c}0.0250 \\
(0.0201)\end{array}$ & $\begin{array}{c}0.0096 \\
(0.0083)\end{array}$ \\
\hline Inflation $_{t-1}$ & $\begin{array}{l}-0.0005 \\
(0.0006)\end{array}$ & $\begin{array}{l}-0.0001 \\
(0.0006)\end{array}$ & $\begin{array}{c}0.0038 \\
(0.0050)\end{array}$ & $\begin{array}{l}-0.0001 \\
(0.0001)\end{array}$ \\
\hline UrbanPop $_{t-1}$ & $\begin{array}{c}0.4980 * * * \\
(0.0266)\end{array}$ & $\begin{array}{c}0.5000 * * * \\
(0.0261)\end{array}$ & $\begin{array}{c}0.4264 * * * \\
(0.0429)\end{array}$ & $\begin{array}{c}0.2219 * * * \\
(0.0708)\end{array}$ \\
\hline Constant & $\begin{array}{c}5.087 * * * \\
(3.566)\end{array}$ & $\begin{array}{c}4.947 * * * \\
(3.601)\end{array}$ & $\begin{array}{c}105.547 * * * \\
(18.358)\end{array}$ & $\begin{array}{c}46.257 * * * \\
(5.423)\end{array}$ \\
\hline Time Fixed Effects & $\mathrm{NO}$ & YES & YES & YES \\
\hline Country Fixed Effects & NO & NO & NO & YES \\
\hline Observations & 489 & 489 & 489 & 489 \\
\hline Number of countries & 117 & 117 & 117 & 117 \\
\hline
\end{tabular}

Appendix A4. Table A4. Inequality and HDI by level of inequality

\begin{tabular}{|c|c|c|c|c|c|c|}
\hline Dependent variables: & $\begin{array}{c}(1) \\
H D I_{t}\end{array}$ & $\begin{array}{c}(2) \\
H D I_{t} \\
\end{array}$ & $\begin{array}{c}(3) \\
H D I_{t} \\
\end{array}$ & $\begin{array}{c}(4) \\
l G D P_{t} \\
\end{array}$ & $\begin{array}{l}(5) \\
\text { Life }_{t} \\
\end{array}$ & $\begin{array}{l}(6) \\
\text { Lit }_{t} \\
\end{array}$ \\
\hline$G i n i_{t-2}$ & $\begin{array}{c}1.1600 * * * \\
(0.2774)\end{array}$ & $\begin{array}{c}0.1847 \\
(0.1862)\end{array}$ & $\begin{array}{l}0.1250 * \\
(0.0740)\end{array}$ & $\begin{array}{c}0.0219 \\
(0.0140)\end{array}$ & $\begin{array}{c}0.1089 \\
(0.1753)\end{array}$ & $\begin{array}{l}-0.0741 \\
(0.3089)\end{array}$ \\
\hline $\operatorname{Gini}_{t-2}^{2}$ & $\begin{array}{c}-0.0126 * * * \\
(0.0036)\end{array}$ & $\begin{array}{c}0.0015 \\
(0.0022)\end{array}$ & & $\begin{array}{l}-0.0002 \\
(0.0002)\end{array}$ & $\begin{array}{l}-0.0011 \\
(0.0022)\end{array}$ & $\begin{array}{l}-0.0008 \\
(0.0037)\end{array}$ \\
\hline $\operatorname{Gini}_{t-2} * H I G H$ & & & $\begin{array}{l}-0.1210 \\
(0.0840)\end{array}$ & & & \\
\hline Controls & $\mathrm{NO}$ & YES & YES & YES & YES & YES \\
\hline Time Fixed Effects & $\mathrm{NO}$ & YES & YES & YES & YES & YES \\
\hline Country Fixed Effects & YES & YES & YES & YES & YES & YES \\
\hline Observations & 510 & 489 & 489 & 489 & 489 & 489 \\
\hline Number of countries & 117 & 117 & 117 & 117 & 117 & 117 \\
\hline
\end{tabular}




\section{TABLES AND FIGURES}

Figure 1. [Social] Human Development Index vs. GDP
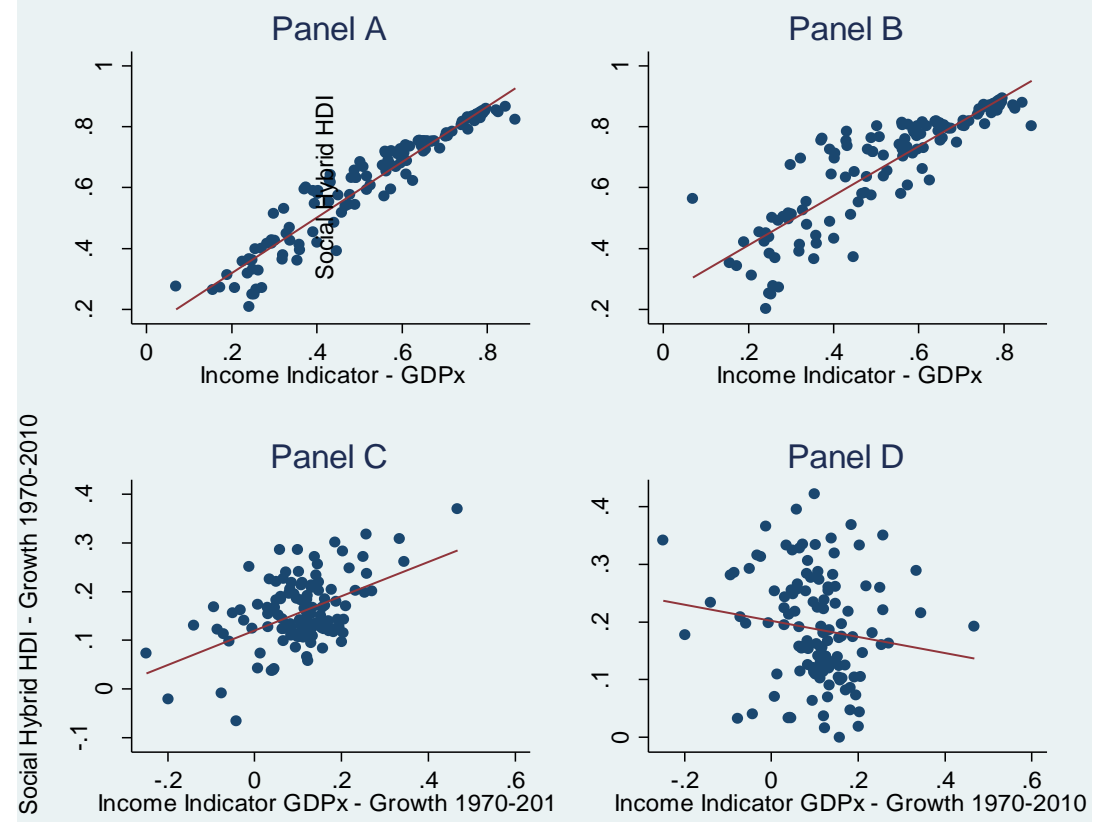

Note: Panel A plots GDP pc against the (Hybrid) HDI. Panel B plots GDP pc against the "Social HDI" (the geometric mean of the education and health indices). Panel C and D replicate panel A and B but considering growth in the variables between 1970 and 2010.

Table 1. Descriptive Statistics

\begin{tabular}{|c|c|c|c|c|c|c|}
\hline & \multirow[t]{2}{*}{ Mean } & \multicolumn{3}{|c|}{ Standard deviation } & \multirow[t]{2}{*}{ Max } & \multirow[t]{2}{*}{ Min } \\
\hline & & Overall & Between & Within & & \\
\hline$H D I(0-100$ index $)$ & 60.94 & 19.05 & 18.25 & 5.69 & 93.83 & 12.53 \\
\hline Life Expectancy (years) & 64.54 & 10.91 & 10.22 & 3.92 & 83.17 & 26.39 \\
\hline Literacy Rate (\%) & 76.02 & 26.29 & 24.97 & 8.49 & 99 & 3.23 \\
\hline Gross Enrol. Rate (\%) & 62.73 & 20.41 & 18.29 & 9.20 & 115.8 & 5.22 \\
\hline$G D P(P P P$ US \$) & 9352.1 & 10686.2 & 10030.8 & 3789.9 & 81101.2 & 163.28 \\
\hline Gini $(0-100$ index $)$ & 36.52 & 9.31 & 8.59 & 3.49 & 62.28 & 17.65 \\
\hline GovConsumption /\%) & 10.08 & 7.03 & 6.21 & 2.98 & 56.80 & 0.83 \\
\hline Investment (\%) & 22.44 & 10.04 & 7.87 & 6.13 & 66.77 & 1.30 \\
\hline Openness (\%) & 68.04 & 46.22 & 38.76 & 24.76 & 398.18 & 3.95 \\
\hline Inflation (\%) & 50.17 & 495.16 & 155.58 & 466.34 & $12,338.66$ & -17.02 \\
\hline UrbanPop (\%) & 50.75 & 23.85 & 23.11 & 6.17 & 100 & 2.85 \\
\hline
\end{tabular}

Note: see Appendix 1 to see the description of the variables. 
Figure 2. Inequality and HDI

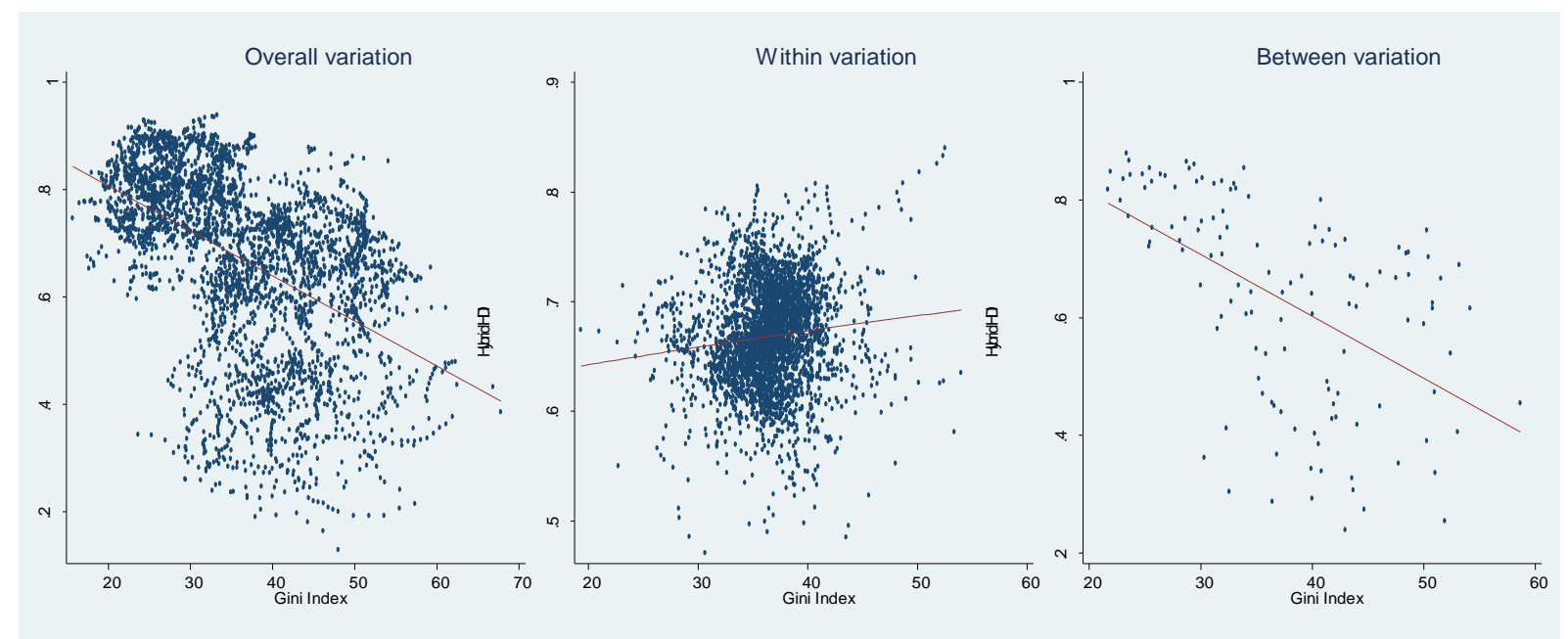

Note: First panel considers overall variation in both the Gini and the (Hybrid) HDI, while the second panel only considers within-countries variation and the third panel only between-countries variation.

Table 2. Correlation between Gini coefficient and HDI

\begin{tabular}{|c|c|c|}
\hline & \multicolumn{2}{|c|}{ Time fixed effects } \\
\hline & No & Yes \\
\hline Country fixed effects & & \\
\hline No & -0.4704 & -0.4748 \\
\hline Yes & 0.1145 & -0.0904 \\
\hline
\end{tabular}

Table 3. Inequality and HDI (and its components), main results

\begin{tabular}{|c|c|c|c|c|}
\hline Dependent variable: & $\begin{array}{c}(1) \\
H D I t\end{array}$ & $\begin{array}{c}(2) \\
l G D P t\end{array}$ & $\begin{array}{l}\text { (3) } \\
\text { Life } t\end{array}$ & $\begin{array}{l}\text { (4) } \\
\text { Lit } t\end{array}$ \\
\hline Gini $_{t-2}$ & $\begin{array}{c}0.0715 \\
(0.0514)\end{array}$ & $\begin{array}{c}0.0091 * * \\
(0.0040)\end{array}$ & $\begin{array}{c}0.0273 \\
(0.0483)\end{array}$ & $\begin{array}{c}-0.144 * \\
(0.0761)\end{array}$ \\
\hline $\begin{array}{l}\text { Observations } \\
\text { Number of countries }\end{array}$ & $\begin{array}{l}489 \\
117\end{array}$ & $\begin{array}{l}489 \\
117\end{array}$ & $\begin{array}{l}489 \\
117\end{array}$ & $\begin{array}{l}489 \\
117\end{array}$ \\
\hline
\end{tabular}

Note: $l G D P$ is GDP per capita in logs, Life is life expectancy at birth, and Lit is the literacy rate. Estimations performed with multiple estimations (100 imputations). All estimations include controls, time and country fixed effects. Robust standard errors in parentheses. $* * * \mathrm{p}<0.01, * * \mathrm{p}<0.05, * \mathrm{p}<0.1$ 
Table 4. Inequality and HDI by level of development

\begin{tabular}{|c|c|c|c|c|}
\hline Dependent variable: & $\begin{array}{l}(1) \\
H D I \\
\end{array}$ & $\begin{array}{c}(2) \\
l G D P\end{array}$ & $\begin{array}{l}(3) \\
\text { Life } \\
\end{array}$ & $\begin{array}{l}(4) \\
\text { Lit } \\
\end{array}$ \\
\hline$G i n i_{t-2}$ & $\begin{array}{l}0.1047 * \\
(0.0585)\end{array}$ & $\begin{array}{c}0.0128 * * * \\
(0.0045)\end{array}$ & $\begin{array}{l}-0.0319 \\
(0.0581)\end{array}$ & $\begin{array}{c}-0.1545 * * \\
(0.0774)\end{array}$ \\
\hline Gini $_{t-2} *$ Developed & $\begin{array}{c}-0.1616^{*} \\
(0.0821)\end{array}$ & $\begin{array}{c}-0.0178 * * * \\
(0.0057)\end{array}$ & $\begin{array}{l}-0.0224 \\
(0.0681)\end{array}$ & $\begin{array}{c}0.0547 \\
(0.1971)\end{array}$ \\
\hline $\begin{array}{l}\text { Observations } \\
\text { Number of countries }\end{array}$ & $\begin{array}{l}489 \\
117\end{array}$ & $\begin{array}{l}489 \\
117\end{array}$ & $\begin{array}{l}489 \\
117\end{array}$ & $\begin{array}{l}489 \\
117\end{array}$ \\
\hline
\end{tabular}

Note: Estimations performed with multiple estimations (100 imputations). All estimations include controls, time and country fixed effects. Robust standard errors in parentheses. $* * * \mathrm{p}<0.01, * *$

Table 5. Cross-section estimates

\begin{tabular}{lccccc}
\hline & $(1)$ OLS & (2) IV & (3) IV & (4) IV & (5) IV \\
Dependent variable: & HDI & HDI & lGDP & Life & Lit \\
\hline & & & & & \\
Inequality & $-0.6539 * * *$ & $-1.786 * * *$ & $-0.1370 * * *$ & $-0.8807 * * *$ & $-1.5998 * * *$ \\
& $(0.1494)$ & $(0.3464)$ & $(0.0252)$ & $(0.1990)$ & $(0.3611)$ \\
& & & & & \\
\hline Observations & 114 & 95 & 95 & 95 & 95 \\
A-P F test & & $33.09 * * *$ & $33.09 * * *$ & $33.09 * * *$ & $33.09 * * *$ \\
Kleibergen-Paap LM-stat & & $34.27 * * *$ & $34.27 * * *$ & $34.27 * * *$ & $34.27 * * *$ \\
Hansen J stat p-value & & 0.283 & 0.564 & 0.131 & 0.148 \\
\hline N & & & & \\
\hline
\end{tabular}

Note: Dependent variables measured in 2010. Inequality measured as the average between 1980 and 2005. In columns 2 to 5 lwheatsugar and tropicar are used as instruments for Inequality. Angrist-Pischke (AP) F tests the significance of excluded instruments. Kleibergen-Paap LM-stat tests the null hypothesis that the equation is underidentified. Hansen $\mathrm{J}$ tests that the excluded instruments are uncorrelated with the error term. Robust standard errors in parentheses. $* * *$ $\mathrm{p}<0.01, * * \mathrm{p}<0.05, * \mathrm{p}<0.1$ 
Table 6. Some robustness checks

\begin{tabular}{|c|c|c|c|c|c|}
\hline & (1) & (2) & (3) & (4) & (5) \\
\hline \multicolumn{6}{|c|}{ Dependent variable: $H D I$ (in 2010 ) } \\
\hline Inequality & $\begin{array}{c}-3.4117 * * * \\
(0.5809)\end{array}$ & $\begin{array}{c}-2.8839 * * \\
(1.452)\end{array}$ & $\begin{array}{c}-4.8981 * * \\
(2.4021)\end{array}$ & $\begin{array}{c}-1.3997 * * * \\
(0.3019)\end{array}$ & $\begin{array}{c}-1.0094 * \\
(0.6098)\end{array}$ \\
\hline Ethfrac & & & & $\begin{array}{c}-0.2590 * * * \\
(0.0645)\end{array}$ & \\
\hline$Q o G$ & & & & & $\begin{array}{c}0.2940 \\
(0.1899)\end{array}$ \\
\hline Observations & 73 & 95 & 95 & 95 & 71 \\
\hline A-P F test & $21.01 * * *$ & 2.32 & $4.20 * *$ & $35.30 * * *$ & $6.89 * * *$ \\
\hline Kleibergen-Paap LM-stat & $21.39 * * *$ & 3.61 & $6.22 * *$ & $30.41 * * *$ & $10.15^{* * *}$ \\
\hline Hansen $\mathbf{J}$ stat p-value & 0.358 & 0.163 & 0.570 & 0.662 & 0.416 \\
\hline
\end{tabular}

Note: All columns report IV estimates with lwheatsugar and tropicar as instruments for Inequality. Column 1 excludes the Americas, column 2 includes regional dummies, and column 3 includes colonial dummies. Angrist-Pischke (AP) F tests the significance of excluded instruments. Kleibergen-Paap LMstat tests the null hypothesis that the equation is underidentified. Hansen $\mathrm{J}$ tests that the excluded instruments are uncorrelated with the error term. Robust standard errors in parentheses. $* * * \mathrm{p}<0.01$, ** $\mathrm{p}<0.05, * \mathrm{p}<0.1$ 


\section{Online Supplementary Material for "Inequality and human underdevelop- ment: insights from an analysis of the Human Development Index"}

\section{The Hybrid HDI:}

The HDI is a multidimensional, composite index of three human development dimensions health, knowledge, and income. It is a geometric mean of life expectancy at birth, PPP-adjusted GNI per capita, and an education index which in turn is measured by expected years of schooling for children and mean years of schooling for adults. The sub-indices are normalized between 0 and 1 , and the aggregated indicator allows for standardized comparison and ranking of countries.

The Hybrid-HDI applies the same aggregation formula as the new HDI to the set of previous indicators - literacy and gross enrollment for the education index and GDP per capita as the income variable. This does not only allow for greater country and year coverage, but is also more suitable to understand past progress (Gidwitz et al., 2010). It is computed as follows:

$$
\text { Hybrid HDI }=\sqrt[3]{\text { Lifex } * E D U x * G D P x}
$$

where:

$$
\begin{aligned}
& \text { Lifex }=\frac{\text { Life }-20}{83.166(\text { Japan }, 2010)-20} \\
& \text { GDPx }=\frac{\ln (\text { GDP }-\ln (163.28143(\text { Liberia }, 1995)}{\ln (106769.74(\text { UAE }, 1977))-\ln (163.28143(\text { Liberia }, 1995))} \\
& \text { EDUx }=\sqrt[2]{\text { Litx } * \text { GERx }}
\end{aligned}
$$

and:

$$
\begin{aligned}
& \text { Litx }=\frac{(\text { Lit }-0)}{99(\text { several countries, several years })-0} \\
& \text { GERx }=\frac{\text { GER }-0}{115.8192(\text { Australia }, 2002)-0}
\end{aligned}
$$

where Lit is the literacy rate, GER the combined gross enrolment rate, Life the Life expectancy at birth, and GDP the Gross Domestic Product per capita, PPP adjusted and measured in dollars.

\section{Online Supplementary Material references}

Gidwitz, Z, Heger, M P, Pineda, J, and Rodríguez, F (2010) Understanding Performance in Human Development: A CrossNational Study (No. HDRP-2010-42). Human Development Research Paper 2010/42. UNDP-HDRO. 